\title{
Front Matter: Volume 8168
}

, "Front Matter: Volume 8168," Proc. SPIE 8168, Advances in Optical Thin Films IV, 816801 (26 October 2011); doi: 10.1117/12.916797

SPIE. Event: SPIE Optical Systems Design, 2011, Marseille, France 


\section{PROCEEDINGS OF SPIE}

\section{Advances in Optical Thin Films IV}

Michel Lequime

H. Angus Macleod

Detlev Ristau

Editors

5-7 September 2011

Marseille, France

Sponsored by

SPIE

Coorganised by

POPsud - Optitec (France)

Cosponsored by

Communauté Urbaine Marseille Provence Métropole (France)

Ville de Marseille (France)

Cooperating Organisation

Schott AG (Germany)

Published by

SPIE 
The papers included in this volume were part of the technical conference cited on the cover and title page. Papers were selected and subject to review by the editors and conference program committee. Some conference presentations may not be available for publication. The papers published in these proceedings reflect the work and thoughts of the authors and are published herein as submitted. The publisher is not responsible for the validity of the information or for any outcomes resulting from reliance thereon.

Please use the following format to cite material from this book:

Author(s), "Title of Paper," in Advances in Optical Thin Films IV, edited by Michel Lequime, H. Angus Macleod, Detlev Ristau, Proceedings of SPIE Vol. 8168 (SPIE, Bellingham, WA, 2011) Article CID Number.

ISSN 0277-786X

ISBN 9780819487940

Published by

SPIE

P.O. Box 10, Bellingham, Washington 98227-0010 USA

Telephone +1 3606763290 (Pacific Time) · Fax +1 3606471445

SPIE.org

Copyright (@ 2011, Society of Photo-Optical Instrumentation Engineers

Copying of material in this book for internal or personal use, or for the internal or personal use of specific clients, beyond the fair use provisions granted by the U.S. Copyright Law is authorized by SPIE subject to payment of copying fees. The Transactional Reporting Service base fee for this volume is $\$ 18.00$ per article (or portion thereof), which should be paid directly to the Copyright Clearance Center (CCC), 222 Rosewood Drive, Danvers, MA 01923. Payment may also be made electronically through CCC Online at copyright.com. Other copying for republication, resale, advertising or promotion, or any form of systematic or multiple reproduction of any material in this book is prohibited except with permission in writing from the publisher. The CCC fee code is 0277-786X/11/\$18.00.

Printed in the United States of America.

Publication of record for individual papers is online in the SPIE Digital Library.

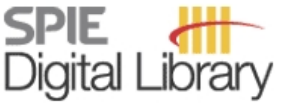

SPIEDigitalLibrary.org

Paper Numbering: Proceedings of SPIE follow an e-First publication model, with papers published first online and then in print and on CD-ROM. Papers are published as they are submitted and meet publication criteria. A unique, consistent, permanent citation identifier (CID) number is assigned to each article at the time of the first publication. Utilization of CIDs allows articles to be fully citable as soon as they are published online, and connects the same identifier to all online, print, and electronic versions of the publication. SPIE uses a six-digit CID article numbering system in which:

- The first four digits correspond to the SPIE volume number.

- The last two digits indicate publication order within the volume using a Base 36 numbering system employing both numerals and letters. These two-number sets start with 00, 01, 02, 03, 04 , 05, 06, 07, 08, 09, OA, OB ... 0Z, followed by 10-1Z, 20-2Z, etc.

The CID number appears on each page of the manuscript. The complete citation is used on the first page, and an abbreviated version on subsequent pages. Numbers in the index correspond to the last two digits of the six-digit CID number. 


\title{
Contents
}

\author{
xi Conference Committee \\ xiii Introduction
}

\section{SESSION 1 OPENING SESSION}

816802 Progress in optical coatings (Invited Paper) [8168-01]

A. Macleod, Thin Film Ctr., Inc. (United States)

\section{SESSION 2 ANTIREFLECTIVE COATINGS}

816803 Ultra-low-reflectance, high-uniformity, multilayer-antireflection coatings on large substrates deposited using an ion-beam sputtering system with a customized planetary rotation stage (Invited Paper) [8168-02]

S. Dligatch, M. Gross, A. Chtanov, Commonwealth Scientific and Industrial Research

Organisation (Australia)

816804 Protective infrared antireflection coating based on sputtered germanium carbide [8168-03]

D. Gibson, E. Waddell, Thin Film Solutions Ltd. (United Kingdom); F. Placido, Univ. of the West of Scotland (United Kingdom)

\section{SESSION 3 COATING DESIGN AND ANALYSIS}

816808 Optimal design for field enhancement in optical coatings (Invited Paper) [8168-07] C. Amra, C. Ndiaye, M. Zerrad, F. Lemarchand, Institut Fresnel, CNRS, Univ. d'Aix-Marseille (France)

816809 Design of multilayer coatings containing metal island films [8168-08]

T. V. Amotchkina, Lomonosov Moscow State Univ. (Russian Federation); J. Sancho-Parramon, V. Janicki, Rudjer Boskovic Institute (Croatia); M. K. Trubetskov, Lomonosov Moscow State Univ. (Russian Federation); H. Zorc, Rudjer Boskovic Institute (Croatia); A. V. Tikhonravov, Lomonosov Moscow State Univ. (Russian Federation)

$81680 \mathrm{~A}$ Investigation of manufacturing processes by numerical sensitivity analysis [8168-09] O. Vasseur, ONERA - The French Aerospace Lab (France); M. Cathelinaud, Mission Ressources et Compétences Technologiques, CNRS, Univ. of Paris-Sorbonne (France)

$8168 \mathrm{OB}$ Application of global optimization algorithms for optical thin film index determination from spectro-photometric analysis [8168-10]

L. Gao, F. Lemarchand, M. Lequime, Institut Fresnel, CNRS, Univ. d'Aix-Marseille (France)

$81680 \mathrm{C}$ Effect of substrate index of refraction on the design of antireflection coatings [8168-11]

R. R. Willey, Willey Optical (United States) 
8168 OD Angular and spectral light scattering from complex multidielectric coatings [8168-12] C. Grèzes-Besset, D. Torricini, H. Krol, CILAS (France); M. Zerrad, M. Lequime, C. Amra, Institut Fresnel, CNRS, Univ. d'Aix-Marseille (France)

$81680 \mathrm{O} \quad$ Robust synthesis of dispersive mirrors (Invited Paper) [8168-13]

V. Pervak, Ludwig-Maximilians-Univ. München (Germany) and Ultrafast Innovations $\mathrm{GmbH}$ (Germany); M. K. Trubetskov, A. V. Tikhonravov, Lomonosov Moscow State Univ. (Russian Federation)

\section{SESSION 4 APPLICATIONS}

8168 OF Optical coatings in space (Invited Paper) [8168-14]

D. Wernham, European Space Agency (Netherlands)

$81680 \mathrm{G}$ Colour control and selectivity in TiAIN solar-thermal absorbers [8168-15]

S. Zhao, Uppsala Univ. (Sweden); D. Zhu, Hefei Univ. of Technology (China); C.-G. Ribbing, Uppsala Univ. (Sweden)

$8168 \mathrm{OH} \quad$ Research on low-polarizing x-plate for LED projector using green phosphors [8168-16] Y.-J. Chen, M.-C. Li, C.-C. Kuo, National Central Univ. (Taiwan); J.-J. Huang, Delta Electronics, Inc. (Taiwan); C.-C. Lee, National Central Univ. (Taiwan)

$81680 \mathrm{~J} \quad$ Coatings for thin-disk laser systems [8168-18]

S. Günster, D. Ristau, Laser Zentrum Hannover e.V. (Germany); B. Weichelt, A. Voss, Univ. Stuttgart (Germany)

\section{SESSION $5 \quad$ DEPOSITION PROCESSES}

8168 OK Atomic layer deposition of iridium thin films and their application in gold electrodeposition (Invited Paper) [8168-19]

A. Szeghalmi, Friedrich Schiller Univ. Jena (Germany); M. Arnold, Chemnitz Univ. of Technology (Germany); A. Berger, N. Schammelt, Max Planck Institute for Microstructure Physics (Germany); K. Fuechsel, Friedrich Schiller Univ. Jena (Germany) and Fraunhofer Institute of Applied Optics and Precision Engineering (Germany); M. Knez, Max Planck Institute for Microstructure Physics (Germany); E. B. Kley, Friedrich Schiller Univ. Jena (Germany); D. R. T. Zahn, Chemnitz Univ. of Technology (Germany); A. Tuennermann, Friedrich Schiller Univ. Jena (Germany) and Fraunhofer Institute of Applied Optics and Precision Engineering (Germany)

$8168 \mathrm{OL} \quad$ Plasma and optical thin film technologies [8168-20]

O. Stenzel, S. Wilbrandt, N. Kaiser, Fraunhofer Institute for Applied Optics and Precision Engineering IOF (Germany); C. Schmitz, M. Turowski, D. Ristau, Laser Zentrum Hannover e.V. (Germany); P. Awakowicz, R. P. Brinkmann, T. Musch, I. Rolfes, Ruhr-Univ. Bochum (Germany); H. Steffen, R. Foest, A. Ohl, Leibniz-Institut für Plasmaforschung und Technologie e.V. (Germany); T. Köhler, G. Dolgonos, T. Fravenheim, Bremen Univ. (Germany)

$8168 \mathrm{ON}$ Optical and thin film properties of mixed oxides deposited by pulsed reactive magnetron sputtering [8168-22]

S. Bruns, M. Vergöhl, Fraunhofer Institute for Surface Engineering and Thin Films IST (Germany) 
$816800 \quad$ New sputtering concept for optical precision coatings [8168-23]

D. Rademacher, G. Bräuer, M. Vergöhl, B. Fritz, T. Zickenrott, Fraunhofer Institute for Surface Engineering and Thin Films IST (Germany)

8168 OP PACA2M: magnetron sputtering for 2-meter optics [8168-24]

G. Chauveau, D. Torricini, C. Grèzes-Besset, CILAS (France); D. Stojcevski, M. Lequime, Institut Fresnel, CNRS, Univ. d'Aix Marseille (France)

\section{SESSION 6 THIN-FILM MATERIALS}

$81680 Q \quad$ Organic small molecule-based optical coatings (Invited Paper) [8168-25]

U. Schulz, C. Präfke, P. Munzert, N. Kaiser, Fraunhofer Institute for Applied Optics and Precision Engineering (Germany)

8168 OR Tailored TCOs [8168-26]

A. Bingel, Friedrich-Schiller-Univ. Jena (Germany); K. Füchsel, Friedrich-Schiller-Univ. Jena (Germany) and Fraunhofer Institute for Applied Optics and Precision Engineering (Germany); N. Kaiser, Fraunhofer Institute for Applied Optics and Precision Engineering (Germany); A. Tünnermann, Friedrich-Schiller-Univ. Jena (Germany) and Fraunhofer Institute for Applied Optics and Precision Engineering (Germany)

8168 OS Spectral density analysis of the optical properties of $\mathrm{Ni}_{-} \mathrm{Al}_{2} \mathrm{O}_{3}$ nano-composite films [8168-27]

G. A. Niklasson, Uppsala Univ. (Sweden); T. K. Boström, NORUT Northern Research Institute AS (Norway); E. Tuncer, GE Global Research Ctr. (United States)

8168 OT Organic materials for the use in optical layer systems [8168-28]

T. Neubert, A. Gaida, W. Huwer, M. Vergöhl, Fraunhofer Institute for Surface Engineering and Thin Films IST (Germany)

\section{SESSION 7 FILTERS AND MANUFACTURING}

$81680 X \quad$ IRDIS filters: from design to qualification (Invited Paper) [8168-32]

H. Krol, N. Valette, D. Torricini, C. Grèzes-Besset, CILAS (France); K. Dohlen, D. Le Mignant, M. Saïsse, G. Moreaux, M. Langlois, C. Moutou, A. Vigan, Marseille-Univ. de Provence (France); F. Lemarquis, Institut Fresnel, CNRS, Univ. Paul Cézanne (France)

8168 OY Exclusive examples of high-performance thin-film optical filters for fluorescence spectroscopy made by plasma-assisted reactive magnetron sputtering [8168-33] M. Lappschies, U. Schallenberg, S. Jakobs, Optics Balzers Jena GmbH (Germany)

$81680 Z$ Manufacturing and characterizing of all-dielectric band-pass filters for the short-wave infrared region [8168-34]

T. Baver, M. Lappschies, U. Schallenberg, S. Jakobs, Optics Balzers Jena GmbH (Germany)

816811 Infrared polarizing beam-splitters for the 7 to $13 \mu \mathrm{m}$ spectral region [8168-36]

L. Li, National Research Council Canada (Canada); J.-M. Thériault, Defence Research and Development Canada (Canada); Y. Guo, National Research Council Canada (Canada) 
816814 Optical performance of narrow-band transmittance filters under low-and high-energy proton irradiation [8168-39]

A. Piegari, I. Di Sarcina, M. L. Grilli, F. Menchini, S. Scaglione, A. Sytchkova, ENEA (Italy)

816815 Study of the laser matter interaction in the femtosecond regime: application to the analysis of the laser damage of optical thin films [8168-40]

B. Mangote, L. Gallais, M. Zerrad, M. Commandré, L. H. Gao, F. Lemarchand, M. Lequime, Institut Fresnel, CNRS, Aix-Marseille Univ. (France); A. Melninkaitis, J. Mirauskas, V. Sirutkaitis, Vilnius Univ. (Lithuania); S. Kicas, T. Tolenis, R. Drazdys, State Research Institute for Physical Sciences and Technology (Lithuania); M. Mende, L. Jensen, H. Ehlers, Laser Zentrum Hannover e.V. (Germany); D. Ristau, Laser Zentrum Hannover e.V. (Germany) and QUEST: Ctr. of Quantum Engineering and Space-Time Research (Germany)

816816 Using monodisperse $\mathrm{SiO}_{2}$ microspheres to study laser-induced damage of nodules in $\mathrm{HfO}_{2} / \mathrm{SiO}_{2}$ high reflectors [8168-42]

X. Cheng, T. Ding, W. He, J. Zhang, H. Jiao, B. Ma, Z. Shen, Z. Wang, Key Lab. of Advanced Micro-structure Materials (China) and Tongji Univ. (China)

\section{SESSION 9 SOFT X-RAY/EUV/DUV/VUV COATINGS}

816817 Design, deposition, and characterization of multilayer mirrors for ultrashort pulses in the attosecond domain (Invited Paper) [8168-43]

S. de Rossi, C. Bourassin-Bouchet, E. Meltchakov, F. Delmotte, Lab. Charles Fabry, CNRS, Univ. Paris Sud (France); Z. Diveki, T. Ruchon, P. Salières, B. Carré, Commissariat à l'Énergie Atomique (France)

816818 Optical, chemical, depth, and magnetic characterization of $\mathbf{M g} / \mathrm{Co}$-based nanometric periodic multilayers [8168-44]

P. Jonnard, K. Le Guen, M.-H. Hu, J.-M. André, Lab. de Chimie Physique-Matière Rayonnement, CNRS, Univ. Pierre et Marie Curie (France); S. K. Zhou, H. C. Li, J. T. Zhu, Z. S. Wang, Tongji Univ. (China); N. Mahne, A. Giglia, S. Nannarone, A. Verna, Lab. Nazionale TASC, CNR (Italy); C. Meny, Institut de Physique et Chimie des Matériaux de Strasbourg, CNRS (France); A. Galtayries, Lab. de Physico-Chimie des Surfaces, CNRS, Ecole Nationale Superieure de Chimie ParisTech (France); I. Estève, Institut de Minéralogie et de Physique des Milieux Condensés, CNRS, Univ. Paris 6 et 7 (France); M. Walls, Lab. de Physique des Solides, CNRS, Univ. Paris-Sud 11 (France)

816819 EUV reflectivity and stability of tri-component Al-based multilayers [8168-45] E. Meltchakov, A. Ziani, Lab. Charles Fabry, Institut d'Optique Graduate School (France); F. Auchere, X. Zhang, Institut d'Astrophysique Spatiale (France); M. Roulliay, Institut des Sciences Moléculaires d'Orsay (France); S. De Rossi, C. Bourassin-Bouchet, A. Jérome, F. Bridou, F. Varniere, F. Delmotte, Lab. Charles Fabry, Institut d'Optique Graduate School (France)

8168 1B Coating development for the far and extreme ultraviolet based on material characterization [8168-47]

J. I. Larruquert, L. Rodríguez-de Marcos, S. García-Cortés, M. Vidal-Dasilva, A. P. Pérez-Marín, J. A. Aznárez, J. A. Méndez, Consejo Superior de Investigaciones Científicas (Spain) 
$81681 \mathrm{C}$ Mg-based multilayers and their thermal stabilities for EUV range [8168-48]

J. Zhu, S. Zhou, H. Li, Q. Huang, L. Jiang, F. Wang, Z. Zhang, Z. Wang, Tongji Univ. (China);

H. Zhou, T. Huo, Univ. of Science and Technology of China (China)

\section{SESSION 10 PROCESS CONTROL AND MONITORING}

8168 1D Broadband monitoring simulation with massively parallel processors (Invited Paper) [8168-49]

M. Trubetskov, T. Amotchkina, A. Tikhonravov, Moscow State Univ. (Russian Federation)

$8168 \mathrm{IE}$ Online re-optimization as a powerful part of enhanced strategies in optical broadband monitoring [8168-50]

S. Schlichting, K. Heinrich, H. Ehlers, D. Ristau, Laser Zentrum Hannover e.V. (Germany)

$8168 \mathrm{lF}$ From independent thickness monitoring to adaptive manufacturing: advanced deposition control of complex optical coatings [8168-51]

H. Ehlers, S. Schlichting, C. Schmitz, D. Ristau, Laser Zentrum Hannover e.V. (Germany)

$81681 G \quad$ Broadband optical monitoring for a 2-meter optics magnetron sputtering deposition machine [8168-52]

D. Stojcevski, M. Lequime, Institut Fresnel, CNRS, Aix-Marseille Univ. (France); G. Chauveau, D. Torricini, C. Grèzes-Besset, CILAS (France)

$8168 \mathrm{1H}$ Optimization of ion-assisted ITO films by design of experiment [8168-53]

S. Schwyn Thöny, J. Buchholz, S. Waldner, Evatec Ltd. (Switzerland)

816811 Modelling and optimization of film thickness variation for plasma enhanced chemical vapour deposition processes [8168-54]

E. Waddell, D. Gibson, Thin Film Solutions Ltd. (United Kingdom); L. Lin, X. Fu, Changchun Univ. of Science and Technology (China)

$81681 \mathrm{~J}$ Testglass changer for direct optical monitoring [8168-55]

A. Zoeller, H. Hagedorn, W. Weinrich, E. Wirth, Leybold Optics GmbH (Germany)

\section{SESSION 11 1D PHOTONIC CRYSTALS AND METAMATERIALS}

$81681 \mathrm{~K}$ Photothermal phenomena in plasmonics and metamaterials (Invited Paper) [8168-56] X. Chen, Y. Chen, M. Yan, J. Wang, J. Hao, KTH Royal Institute of Technology (Sweden); M. Qiu, KTH Royal Institute of Technology (Sweden) and Zhejiang Univ. (China)

$81681 \mathrm{~L}$ Enhancement of omnidirectional bandgaps by one-dimensional ternary photonic crystals [8168-57]

G. V. Morozov, F. Placido, Univ. of the West of Scotland (United Kingdom)

$81681 \mathrm{M}$ Re-definition of effective refractive index of thin film buried quantum dots [8168-58]

Y.-J. Chen, C.-C. Lee Schmidt, National Central Univ. (Taiwan); F. Flory, Aix-Marseille Univ. (France) 
$81681 \mathrm{~N}$ Nanostructures versus thin films in the design of antireflection coatings [8168-59]

U. B. Schallenberg, Optics Balzers Jena GmbH (Germany)

$81681 \mathrm{P}$ Two waves interaction in layered photonic structure at big phase mismatching [8168-61]

V. A. Trofimov, T. M. Lysak, Lomonosov Moscow State Univ. (Russian Federation)

\section{POSTER SESSION}

$81681 Q$ Thickness uniformity improvement for the twin mirrors used in advanced gravitational wave detectors [8168-62]

B. Sassolas, Q. Benoît, R. Flaminio, D. Forest, J. Franc, M. Galimberti, A. Lacoudre, C. Michel, J.-L. Montorio, N. Morgado, L. Pinard, Lab. des Matériaux Avancés, CNRS, Univ. Paris-Est Créteil (France)

8168 is Aluminum based multilayers systems synthesized by ion beam sputtering for extreme UV [8168-64]

A. Ziani, Lab. Charles Fabry, Institut d'Optique Graduate School (France) and Ctr. National d'Études Spatiales (France); F. Delmotte, Lab. Charles Fabry, Institut d'Optique Graduate School (France); C. Le Paven-Thivet, Institut d'Electronique et Télécommunications de Rennes (France); E. Meltchakov, F. Bridou, A. Jérome, Lab. Charles Fabry, Institut d'Optique Graduate School (France); M. Roulliay, Lab. d'Interaction du Rayonnement X, CNRS, Univ. Paris-Sud (France); K. Gasc, Ctr. National d'Études Spatiales (France)

$81681 \mathrm{U}$ Energy logistics in an all-optical adder based on a 1D porous silicon photonic crystal [8168-66]

E. Y. Glushko, Institute of Semiconductor Physics (Ukraine)

$81681 \mathrm{~V}$ Interface plasmonic properties of silver coated by ultrathin metal oxides [8168-67] A. Sytchkova, D. Zola, M. L. Grilli, A. Piegari, ENEA (Italy); M. Fang, H. He, J. Shao, Shanghai Institute of Optics and Fine Mechanics (China)

8168 IW Optical and mechanical properties of oxide UV coatings, prepared by PVD techniques [8168-68]

O. Stenzel, M. Schürmann, S. Wilbrandt, N. Kaiser, A. Tünnermann, Fraunhofer Institute for Applied Optics and Precision Engineering (Germany); M. Mende, H. Ehlers, D. Ristau, Laser Zentrum Hannover e.V. (Germany); S. Bruns, M. Vergöhl, Fraunhofer Institute for Surface Engineering and Thin Films (Germany); W. Riggers, Laseroptik GmbH (Germany); M. Bischoff, Qioptiq Photonics GmbH \& Co. KG (Germany); M. Held, Bte Bedampfungstechnik GmbH (Germany)

$81681 \mathrm{Y}$ Band-pass and OH-suppression filters for the E-ELT: design and prototyping [8168-70] S. Günster, D. Ristau, Laser Zentrum Hannover e.V. (Germany); R. Davies, Max-Planck-Institut für extraterrestrische Physik (Germany)

$81681 \mathrm{Z}$ Investigation of the optical property and structure of $\mathrm{WO}_{3}$ thin films with different sputtering depositions [8168-71]

H.-C. Chen, National Yunlin Univ. of Science and Technology (Taiwan); D.-J. Jan, Institute of Nuclear Energy Research (Taiwan); C.-H. Chen, K.-T. Huang, Y.-M. Lo, National Yunlin Univ. of Science and Technology (Taiwan); S.-H. Chen, National Central Univ. (Taiwan) 
816820 Residual stress analysis for oxide thin film deposition on flexible substrate using finite element method [8168-72]

H.-C. Chen, National Yunlin Univ. of Science and Technology (Taiwan) and National Central Univ. (Taiwan); C.-Y. Huang, S.-S. Lin, National Yunlin Univ. of Science and Technology (Taiwan); S.-H. Chen, National Central Univ. (Taiwan)

816821 Laser-induced damage of pure and mixture material high reflectors for $355 \mathrm{~nm}$ and $1064 \mathrm{~nm}$ wavelength [8168-73]

M. Mende, L. O. Jensen, H. Ehlers, Laser Zentrum Hannover e.V. (Germany); W. Riggers, Laseroptik GmbH (Germany); H. Blaschke, JENOPTIK Optical Systems GmbH (Germany); D. Ristau, Laser Zentrum Hannover e.V. (Germany) and QUEST: Ctr. of Quantum Engineering and Space-Time Research (Germany)

816822 Resonances determination in microstructured films embedded in multilayered stacks [8168-74]

B. Vial, Institut Fresnel, CNRS, Univ. Aix-Marseille III (France) and Silios Technologies (France); M. Commandré, F. Zolla, A. Nicolet, Institut Fresnel, CNRS, Univ. Aix-Marseille III (France); S. Tisserand, Silios Technologies (France)

816825 Investigation of ion beam properties and coating material during IBS [8168-77] M. Jupé, S. Malobabic, Laser Zentrum Hannover e.V. (Germany) and QUEST: Ctr. for Quantum Engineering and Space-Time Research (Germany); C. Schmitz, Laser Zentrum Hannover e.V. (Germany); C. Gouldieff, Institut Fresnel (France); H. Steffen, R. Wiese, Leibniz-Institute for Plasma Science and Technology e.V. (Germany); D. Ristau, Laser Zentrum Hannover e.V. (Germany) and QUEST: Ctr. for Quantum Engineering and Space-Time Research (France)

Author Index 
Downloaded From: https://www.spiedigitallibrary.org/conference-proceedings-of-spie on 26 Apr 2023

Terms of Use: https://www.spiedigitallibrary.org/terms-of-use 


\title{
Conference Committee
}

\author{
Symposium Chair
}

Michel Lequime, Institut FRESNEL and Ecole Centrale Marseille (France)

Symposium Cochairs

Andreas Tünnermann, Fraunhofer-Institut für Angewandte Optik und Feinmechanik (Germany)

David M. Williamson, West Malvern (United Kingdom) and Nikon

Research Corporation of America (United States)

Conference Chairs

Michel Lequime, Institut FRESNEL and Ecole Centrale Marseille (France)

H. Angus Macleod, Thin Film Center, Inc. (United States)

Detlev Ristau, Laser Zentrum Hannover e.V. (Germany)

Program Committee

Claude Amra, Institut Fresnel (France)

Bertrand G. Bovard, Teledyne Scientific Company (United States)

Mireille Commandré, Institut Fresnel (France)

Franck Delmotte, Laboratoire Charles Fabry, Institut d'Optique (France)

Angela Duparré, Fraunhofer-Institut für Angewandte Optik und Feinmechanik (Germany)

Norbert Kaiser, Fraunhofer-Institut für Angewandte Optik und Feinmechanik (Germany)

Juan Ignacio Larruquert, Consejo Superior de Investigaciones Científicas, Instituto de Óptica (Spain)

Xu Liu, Zhejiang University (China)

Ludvik Martinu, Ecole Polytechnique de Montréal (Canada)

Angela M. Piegari, ENEA (Italy)

Frank Placido, University of the West of Scotland (United Kingdom)

Carl G. Ribbing, Uppsala University (Sweden)

Ulrike Schulz, Fraunhofer-Institut für Angewandte Optik und Feinmechanik (Germany)

Christopher J. Stolz, Lawrence Livermore National Laboratory (United States)

Alexander V. Tikhonravov, Lomonosov Moscow State University

(Russian Federation)

Hrvoje Zorc, Institut Ruder Boškovic (Croatia) 
Session Chairs

1 Opening Session

Detlev Ristau, Laser Zentrum Hannover e.V. (Germany)

2 Antireflective Coatings

H. Angus Macleod, Thin Film Center, Inc. (United States)

Detlev Ristau, Laser Zentrum Hannover e.V. (Germany)

3 Coating Design and Analysis

Bertrand G. Bovard, Teledyne Scientific Company (United States)

Desmond R. Gibson, Thin Film Solutions Ltd. (United Kingdom)

$4 \quad$ Applications

Mireille Commandré, Institut Fresnel (France)

Ulrike Schulz, Fraunhofer-Institut für Angewandte Optik und Feinmechanik (Germany)

5 Deposition Processes

Angela M. Piegari, ENEA (Italy)

Juan Ignacio Larruquert, Consejo Superior de Investigaciones Científicas (Spain)

6 Thin-film Materials

Xu Liu, Zhejiang University (China)

Ronald R. Willey, Willey Optical (United States)

$7 \quad$ Filters and Manufacturing

Frank Placido, University of the West of Scotland (United Kingdom)

Ludvik Martinu, Ecole Polytechnique de Montréal (Canada)

8 Characterization

Norbert Kaiser, Fraunhofer-Institut für Angewandte Optik und Feinmechanik (Germany)

Franck Delmotte, Institut d'Optique Graduate School (France)

9 Soft X-ray/EUV/DUV/VUV Coatings

Ulrike Schulz, Fraunhofer-Institut für Angewandte Optik und Feinmechanik (Germany)

Ric P. Shimshock, MLD Technologies, LLC (United States)

10 Process Control and Monitoring

Claude Amra, Institut Fresnel (France)

Carl G. Ribbing, Uppsala University (Sweden)

11 ID Photonic Crystals and Metamaterials

H. Angus Macleod, Thin Film Center, Inc. (United States)

Detlev Ristau, Laser Zentrum Hannover e.V. (Germany) 


\section{Introduction}

The conference on Advances in Optical Thin Films stands in a long tradition of events dedicated to optical coatings organised within SPIE symposia for many years. The present conference is the fourth in a row which started in St. Etienne in 2003 and was continued in Jena, 2005, as well as Glasgow, 2008, within the framework of SPIE Optical Systems Design. The present conference, located in the city of Marseille near the Vieux Port, again reflects recent trends in optical coating technology and gives a comprehensive overview on state of the art developments in the field. This is clearly demonstrated by the number of nearly 80 presenters who contributed to this conference (fig. 1), a high level as in Jena 2005 and St. Etienne 2003. In this context, the slightly lower number of publications in Glasgow may be attributed the economic recession at that time. During the conference, sessions were concentrated on antireflective coatings, coating design and analysis, applications, deposition processes, thin-film materials, filters and manufacturing, characterization, soft $x$ ray/EUV/DUV/VUV coatings, and process control and monitoring, as well as ID photonic crystals and metamaterials. In this constellation (fig. 2) the conference offered a broad range of topics and gathered scientific work in many areas of optical thin film technology. Considering further statistics, the conference was attended by more 150 scientists and benefitted from the framework of the Optical Systems Design symposium.

The internationality of the conference has always been extensively supported by the international program committee, representing research activities in different countries. Presently, the international program committee consists of representatives from France, the United States, Germany, Spain, China, Canada, Italy, the United Kingdom, Sweden, Russia, and Croatia. The engagement of the international program committee, which initiated participation from more than 20 countries during recent years, is acknowledged here as being very important. An especially interesting and encouraging development was the Chinese scientific community and its rank of third in countries contributing to this conference. This increase clearly indicates the enormous growth and progress of the scientific activities in the Pacific Rim and promises even more advances in thin film technology for the near future. Only France and Germany supported the conference by a higher number of publications which were also driven by many industrial research programs as well as by new aspects of fundamental research. The conference proceedings published by SPIE illustrate the enormous vitality of the field and can be considered an important resource compiled in the optical coating area. The tremendous efforts of the authors to prepare the manuscripts and posters are gratefully acknowledged here.

Much of the success of the meeting can be attributed to the tireless efforts of the SPIE staff, as well as many others working hard to support the conference. The organizers also appreciate the cosponsors: Marseille Provence Metropole, POP Sud, Ville de Marseille, and Schott. 


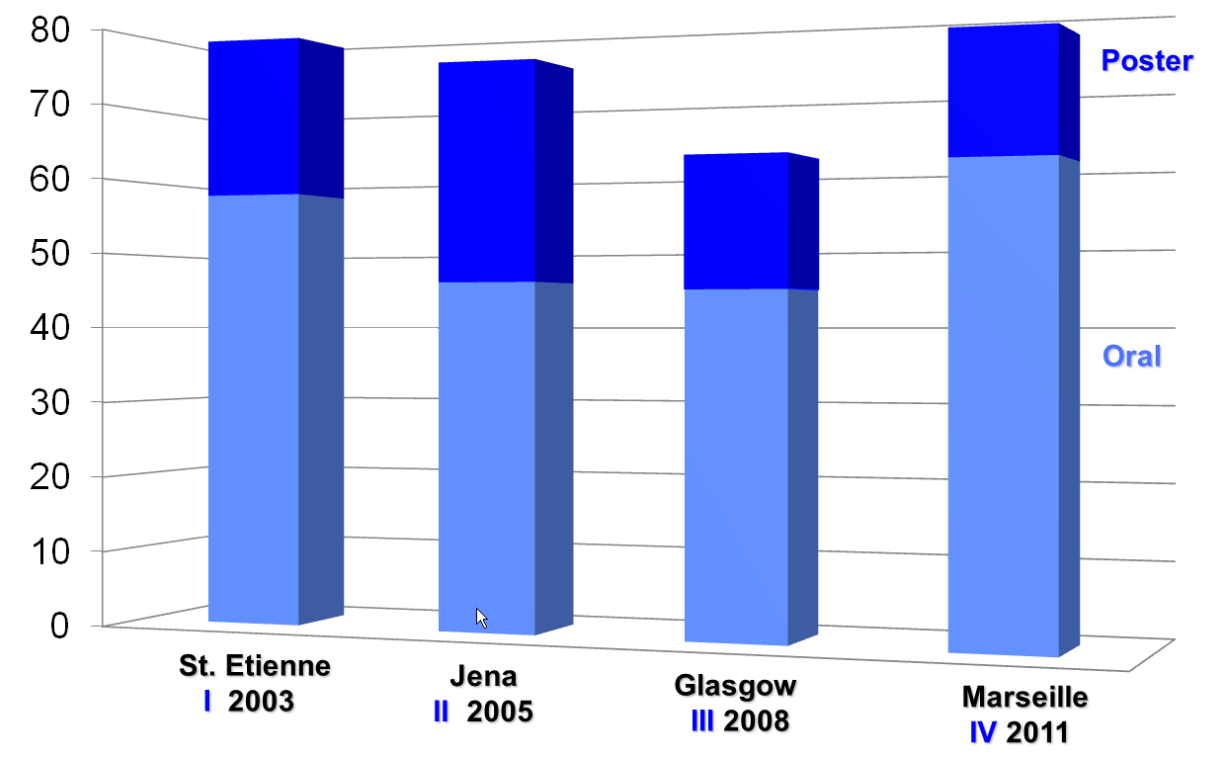

Figure 1: Number of oral and poster presentation contributed the Conference "Advances in Optical Thin Films"

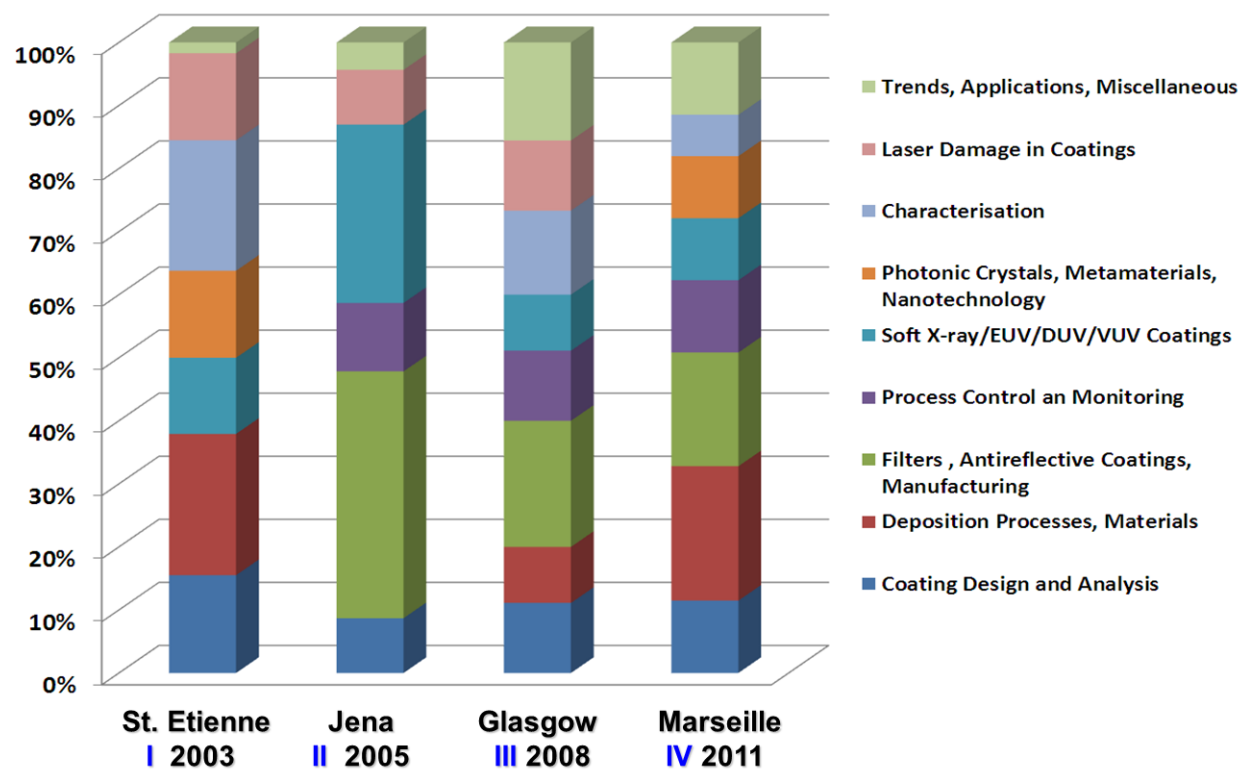

Figure 2: Percentage of oral presentation contributed to topics of the Conference 